\title{
Screening of Psychiatric Patients for Hypovitaminosis $B_{\mathbf{x} 2}$
}

\author{
F. MURPHY,* M.B., M.R.C.P.GLASG. ; P. C. SRIVASTAVA, $\dagger$ M.D., B.SC. \\ S. VARADI, $\ddagger$ M.D., F.C.PATH. ; A. ELWIS,§ F.I.M.L.T.
}

\begin{abstract}
Cummary : Vitamin $B_{12}$ assays and inspection of peripheral blood films performed on 1,004 consecutive new patients over the age of 50 admitted to mental hospital led to the discovery of pernicious anaemia in only two cases. It is concluded that routine vitamin $B_{12}$ assays are justified only when fully-automated techniques have become available.
\end{abstract}

\section{Introduction}

It has long been known that deficiency of vitamin $B_{12}$ may be associated with psychiatric symptoms which are so severe as to dominate the clinical picture of the deficiency and lead to the patient's admission to a mental hospital. In most instances such patients are anaemic, but cases in which there was no overt anaemia and cases in which mental illnesses were associated with normal haemoglobin levels and normal red cell and white cell morphology, but with low serum levels of vitamin $B_{12}$ and impaired absorption of vitamin $B_{12}$, have been reported (Strachan and Henderson, 1965). Such instances of haematologically latent pernicious anaemia would seem to be rare. There has been much discussion about screening procedures for hypovitaminosis $B_{12}$ in psychiatric cases, and the present investigation was undertaken to compare the value of inspection of peripheral blood film morphology with vitamin $\mathrm{B}_{12}$ and folate assays in the routine screening of psychiatric patients.

Inspection of peripheral blood films and assays of serum vitamin $B_{12}$ and folate were performed on 1,004 patients aged 50 or over admitted between July 1967 and March 1969 to a large mental hospital. In the case of 37 patients in this age group the peripheral films were inspected but the serum vitamin $B_{12}$ level was not estimated, while in six cases the serum vitamin $\mathrm{B}_{12}$ was assayed but no blood films were available. In a further 23 cases the patient had died or had been discharged before any specimens could be obtained.

\section{Methods}

Peripheral films were examined for the presence of hypersegmentation of the neutrophils and macrocytosis. Neutrophils counted as hypersegmented contained at least five nuclear lobes, which were usually connected by very fine filaments. Percentage counts of hypersegmentation were not done, but the films were scored as showing hypersegmentation, \pm+ , or ++ . This scoring method was found to be, with experienced observers, as adequate as, and more economical in time than, the percentage hypersegmented cell count.

Assays.-The serum levels of vitamin $\mathrm{B}_{12}$ were assayed either by the microbiological (Euglena gracilis) method (Anderson, 1964) or, in some cases, by an isotopic method (Lau et al., 1965). Serum vitamin $B_{12}$ concentrations of $100-150 \mathrm{pg} . / \mathrm{ml}$. measured by the $E$. gracilis method were considered to be in the "intermediate" range, and concentrations less than $100 \mathrm{pg} . / \mathrm{ml}$. were regarded as "low." Every vitamin $B_{12}$ level found to be below $200 \mathrm{pg} . / \mathrm{ml}$. by the isotopic method was confirmed microbio-

- Senior Registrar.

† Registrar.

Consultant Haematologist.

5 Chief Technician, Assay and Isotope Unit.

Department of Haematology, Northern General Hospital, Sheffield. logically. Serum folate was estimated initially by the method of Waters and Mollin (1961), but later by the aseptic addition method (Herbert, 1966). Red blood cell folate was assayed by the method of Hoffbrand et al. (1966).

Vitamin $B_{12}$ Absorption Tests.-The method of Coupland (1966) was used and the eight-hour plasma concentration, expressed as percentage of the oral dose of ${ }^{58} \mathrm{Co} \mathrm{B}_{12}$ per litre of plasma, was measured. Whenever possible the 24-hour urinary excretion of ${ }^{58} \mathrm{Co} \mathrm{B}_{12}$ was also measured.

\section{Results}

The results are summarized in Table I. Some degree of macrocytosis of the red blood cells was seen in six cases. Of these six films there was an associated ++ neutrophilic hypersegmentation in five cases and + hypersegmentation in one case. In all these cases the serum folate was less than $3 \mathrm{ng} . / \mathrm{ml}$. and in one case the serum vitamin $B_{12}$ was also low.

Vitamin $B_{12}$ Absorption Studies.-Tests of vitamin $B_{12}$ absorption were carried out in 7 of the 25 patients with serum vitamin $B_{12}$ levels between 100 and $150 \mathrm{pg} . / \mathrm{ml}$. (when pressure of laboratory work permitted, and the patient was co-operative). In all seven instances absorption was normal. The results in nine patients with a serum vitamin $B_{12}$ value of less than 100 pg. $/ \mathrm{ml}$. are shown in Table II. It can be seen that two of the nine patients (Cases 3 and 6 ) had the vitamin $B_{12}$ absorption pattern of pernicious anaemia-that is, defective absorption of vitamin $B_{12}$ was corrected by a potent preparation of hog intrinsic factor. ${ }^{1}$

\section{Discussion}

In this series of 1,004 patients routine examination of the peripheral blood films combined with serum vitamin $B_{12}$ estimations led to the discovery of two cases (Cases 3 and 6) of pernicious anaemia. One patient (Case 4) who had an abnormal peripheral film and a low serum vitamin $B_{12}$ level died before the ${ }^{58} \mathrm{Co} \mathrm{B}_{12}$ absorption test could be undertaken.

As the incidence of pernicious anaemia in people of a comparable age group (over 60) is 7 per 1,000 (Mosbech, 1967) there is no evidence from this series that pernicious anaemia is unduly frequent in elderly psychiatric cases.

In each of these three instances the peripheral blood picture was abnormal, and had inspection of the peripheral film been used as the sole screening procedure these cases would not have been missed. In one instance (Case 1 ) the serum vitamin $B_{12}$ was in the low range (100 pg./ml.) but the film was normal; the absorption of ${ }^{57} \mathrm{Co} \mathrm{B}_{12}$ was, however, normal.

In most cases hypersegmentation of the neutrophils was not due to vitamin $B_{12}$ deficiency, but the more pronounced the hypersegmentation the more likely was it due to vitamin $B_{12}$ deficiency. One-third of the cases with + or ++ degree of hypersegmentation had both normal vitamin $B_{12}$ and serum folate levels below $3 \mathrm{ng} . / \mathrm{ml}$. (Table I). Many patients $(25 \%$ ) with normal blood films had serum folate levels below 3 ng./ $\mathrm{ml}$. Furthermore, hypersegmentation of the neutrophils was

\footnotetext{
' Supplied by courtesy of Dr. Leon Ellenbogen, Lederle Laboratories,

New York.
} 
noted when the films of patients with normal folate levels were inspected. Hypersegmentation of the neutrophils may be seen with serum folate levels higher than $3 \mathrm{ng} . / \mathrm{ml}$., probably as an expression of early folate deficiency (Hoffbrand and Newcombe, $1967)$. In the six instances where macrocytosis was noted hypersegmentation was always present.

If the criterion for further investigation of a patient-by assaying the serum vitamin $\mathrm{B}_{12}$ and then, if indicated, performing tests of vitamin- $\mathrm{B}_{12}$ absorption-had been the presence of at least + of neutrophil hypersegmentation vitamin $B_{12}$ assays would have been required in 71 patients. This would represent a considerable saving in time and expense. The use of the investigation for antigastric antibodies described by Henderson et al. (1966) also cuts down the number of patients requiring further investigations to less than $10 \%$. It has, however, the disadvantage that if it were used as the only screening procedure cases of vitamin $\mathrm{B}_{12}$ deficiency following gastrointestinal surgery might be missed (Weir and Webb, 1966 ; Hunter et al., 1967) and peripheral blood film abnormalities, besides those due to vitamin $B_{12}$ or folate deficiency, would not be seen. Thus as regards primary screening of patients for vitamin- $B_{12}$ deficiency the inspection of the peripheral films was satisfactory. This accords with Shulman's (1967a ; 1967b) findings.

With respect to folate deficiency, however, the position is quite different. Minor degrees of neutrophilic hypersegmentation were associated with serum folate levels above $3 \mathrm{ng} . / \mathrm{ml}$. in several instances and in many others the serum folate level was low without there being any findings in the blood films suggestive of folate deficiency. It would seem that low serum folate levels $(<3 \mathrm{ng} . / \mathrm{ml}$.) are very common in elderly patients admitted to the psychiatric hospital, but it is hard to know what significance should be attached to this finding. It is likely that most of these low levels were due to dietary deficiency resulting presumably from the capricious appetites and apathy of the patients. A good hospital diet might well rectify the folate deficiency, but ensuring that the patient eats the diet is, of course, difficult.

Hence, vitamin $B_{12}$ estimation in the older psychiatric patient would be useful mainly to allow folate supplements to be given where the serum vitamin $B_{12}$ level is normal and grounds for suspecting folate deficiency exist.

In the Sheffield Regional Hospital Board's area, covering $4,600,000$ people, there were 5,861 admissions of patients aged 50 or over during 1967. Routine screening of these patients would be impracticable unless a reliable fully automated method for vitamin $B_{12}$ assays was available. At the present time careful inspection of the peripheral film appears to be the most economical primary screening test for vitamin $\mathrm{B}_{12}$ deficiency. Based on our experience of over 1,000 consecutive new patients admitted to a mental hospital over the age of 50 routine vitamin $\mathrm{B}_{12}$ assays in psychiatric patients are no more indicated than in the population at large. Indications for assays should be based on haematological grounds (Varadi et al., 1966).

It is not the purpose of this paper to discuss the clinical findings, but of the patients in whom the serum vitamin $B_{12}$ levels were less than $50 \mathrm{pg} . / \mathrm{ml}$. two (Cases 1 and 3) are still in the mental hospital with essentially unchanged symptomatology (depression). The third patient (Case 6), who was found to have pernicious anaemia, had a good haematological response to vitamin $B_{12}$, but though discharged from hospital still remained rather depressed. Thus the hypovitaminosis $B_{12}$ may have been coincident with rather than responsible for the mental illness in these instances. In those patients with low vitamin $B_{12}$ levels but normal absorption (13 out of 15 examined) the hypovitaminosis was presumably secondary to inadequate diet.

We are grateful for the co-operation provided by Drs. W. D. Addis, J. R. Cox, Elizabeth Gemmell, N. L. Gittleson, A. Kelly, R. J. Kerry, D. Parkin, F. G. Spear, and J. H. S. Whyte, consultant psychiatrists at Middlewood Hospital, Sheffield, and for clinical data provided by Dr. Spear and Dr. Whyte. We would also wish to thank Dr. C. M. Stanbridge and the technical staff of the haematology department, Northern General Hospital, Sheffield, for their help in this study.

\section{REFERENCES}

Anderson, B. B. (1964). Fournal of Clinical Pathology, 17, 14.

Coupland, W. W. (1966). Medical fournal of Australia, 1, 1020.

Edwin, E., Holten, K., Norum, K. R., Schrumpf, A., and Skaug, O. E. (1965). Acta Medica Scandinavica, 177, 689.

Henderson, J. G., Strachan, R. W., Beck, J. S., Dawson, A. A., and Daniel, M. (1966). Lancet, 2, 809.

Herbert, V. (1966). Fournal of Clinical Pathology, 19, 12.

Hoffbrand, A. V., and Newcombe, B. F. A. (1967). British fournal of Haematology, 13, 954.

Haematology, 13, 954.
Hoffbrand, A. V., Newcombe, B. F. A., and Mollin, D. L. (1966). fournal of Clinical Pathology, 19, 17.

Hunter, R., Jones, M., and Matthews, D. M. (1967). Lancet, 1, 47. Lau, K. S., Gottlieb, C., Wasserman, L. R., and Herbert, V. (1965). Blood, 26, 202.

Mosbech, J. (1967). British Medical fournal, 2, 652.

Sheffield Regional Hospital Board Mental Health Enquiry Statistical Tables, 1967.

Shulman, R. (1967a). British fournal of Psychiatry, 113, 241.

Shulman, R. (1967b). British Medical fournal, 3, 266.

Shulman, R. (1967b). British Medical fournal, 3, 266. Medicine, 34, 303 .

Varadi, S., Ewis, A., and Reed, E. R. (1966). Proceedings of the 11th Congress of the International Society of Haematology, p. 215. Sydney, Blight.

Waters, A. H., and Mollin, D. L. (1961). Fournal of Clinical Pathology, 14, 335 .

Weir, D. G., and Webb, M. G. T. (1966). Lancet, 2, 1419.

TABLE I.-Results in 1,004 Cases

\begin{tabular}{|c|c|c|c|c|c|c|c|c|c|}
\hline \multirow{2}{*}{$\begin{array}{l}\text { Total } \\
\text { No. of } \\
\text { Cases }\end{array}$} & \multirow{2}{*}{$\begin{array}{l}\text { Hyperseg- } \\
\text { mentation }\end{array}$} & \multicolumn{3}{|c|}{ Serum $B_{12}$ Levels in $\mathrm{pg} . / \mathrm{ml}$. } & \multicolumn{4}{|c|}{ Serum Folate Levels in $\mathrm{ng} . / \mathrm{ml}$. } & \multirow{2}{*}{$\begin{array}{l}\text { Normal } B_{12} \text { and } \\
>3 \mathrm{ng} . / \mathrm{ml} \text {. } \\
\text { Folate Levels }\end{array}$} \\
\hline & & $>150$ & $100-150$ & $<100$ & $>3$ & $2-3$ & $1-2$ & $<1$ & \\
\hline $\begin{array}{r}809 \\
124 \\
51 \\
20\end{array}$ & $\begin{array}{c}\text { Absent } \\
\pm \\
+ \\
++\end{array}$ & $\begin{array}{c}787(97 \cdot 3 \%) \\
119(96 \cdot 8 \%) \\
47(92 \cdot 1 \%) \\
17(85 \%)\end{array}$ & $\begin{array}{l}19(2.3 \%) \\
3(2.4 \%) \\
3(5.9 \%) \\
0\end{array}$ & $\begin{array}{c}3(0.4 \%) \\
2(1.8 \%) \\
1(2 \%) \\
3(15 \%)\end{array}$ & $\begin{array}{r}608 \\
77 \\
19 \\
8\end{array}$ & $\begin{array}{r}132 \\
29 \\
15 \\
3\end{array}$ & $\begin{array}{r}64 \\
16 \\
14 \\
8\end{array}$ & $\begin{array}{l}5 \\
2 \\
3 \\
1\end{array}$ & $\begin{array}{c}0 \\
76(70 \%) \\
16(31 \cdot 2 \%) \\
6(30 \%)\end{array}$ \\
\hline
\end{tabular}

TABLE II.-Results in Nine Cases with Serum Vitamin $B_{12}$ Less than $100 \mathrm{pg} . / \mathrm{ml}$.

\begin{tabular}{|c|c|c|c|c|c|c|c|c|c|c|}
\hline \multirow{2}{*}{$\begin{array}{l}\text { Case } \\
\text { No. }\end{array}$} & \multirow{2}{*}{ Age } & \multirow{2}{*}{$\begin{array}{l}\mathrm{Hb} \\
(\mathrm{g} . / 100 \mathrm{ml} .)\end{array}$} & \multirow{2}{*}{$\begin{array}{l}\text { P.C.V. } \\
(\%)\end{array}$} & \multirow{2}{*}{$\begin{array}{c}\text { Hyper- } \\
\text { segmentation }\end{array}$} & \multirow{2}{*}{ Bone Marrow } & \multirow{2}{*}{$\begin{array}{c}\text { Serum } \\
\mathrm{B}_{12} \\
\mathrm{pg} \cdot / \mathrm{ml}\end{array}$} & Serum Fo & R.C. Folate & \multicolumn{2}{|c|}{ B $_{12}$ Absorption } \\
\hline & & & & & & & \multicolumn{2}{|c|}{ ng. $/ \mathrm{ml}$. } & Without I.F. & With I.F. \\
\hline $\begin{array}{l}1 \\
2 \\
3\end{array}$ & $\begin{array}{l}67 \\
61 \\
79\end{array}$ & $\begin{array}{l}13 \cdot 0 \\
13 \cdot 3 \\
13 \cdot 3\end{array}$ & $\begin{array}{l}41 \\
36 \\
42\end{array}$ & $\begin{array}{l}0 \\
\pm \\
+\end{array}$ & $\begin{array}{l}\text { N.D. } \\
\text { N.D. } \\
\text { Normoblastic. Few }\end{array}$ & $\begin{array}{l}46 \\
97 \\
30\end{array}$ & $\begin{array}{r}2 \cdot 3 \\
7 \cdot 6 \\
15 \cdot 0\end{array}$ & $\begin{array}{r}237 \\
73 \\
134\end{array}$ & $\begin{array}{l}\text { Normal } \\
\text { Normal } \\
\text { Low }\end{array}$ & Corrected \\
\hline $\begin{array}{l}4 \\
5 \\
6\end{array}$ & $\begin{array}{l}68 \\
70 \\
75\end{array}$ & $\begin{array}{l}12 \cdot 5 \\
12 \cdot 2 \\
11 \cdot 8\end{array}$ & $\begin{array}{l}38 \\
38 \\
36\end{array}$ & $\begin{array}{l}++ \\
0 \\
++\end{array}$ & $\begin{array}{l}\text { N.D.M. } \\
\text { N.D. } \\
\text { Had B12 before B.M. } \\
\text { responded (P.C.V. }\end{array}$ & $\begin{array}{l}68 \\
83 \\
30\end{array}$ & $\begin{array}{r}9 \cdot 0 \\
4 \cdot 3 \\
17 \cdot 0\end{array}$ & $\begin{array}{l}214 \\
147 \\
200\end{array}$ & $\begin{array}{l}\text { N.D. (died) } \\
\text { Normal } \\
\text { Low }\end{array}$ & Corrected \\
\hline $\begin{array}{l}7 \\
8 \\
9\end{array}$ & $\begin{array}{l}79 \\
76 \\
89\end{array}$ & $\begin{array}{l}14 \cdot 4 \\
13 \cdot 7 \\
12 \cdot 6\end{array}$ & $\begin{array}{l}48 \\
45 \\
41\end{array}$ & $\begin{array}{l}++ \\
0 \\
\pm\end{array}$ & $\begin{array}{l}\text { N.D. } \\
\text { N.D. } \\
\text { Normal }\end{array}$ & $\begin{array}{l}94 \\
88 \\
72\end{array}$ & $\begin{array}{l}2 \cdot 1 \\
4 \cdot 4 \\
1 \cdot 7\end{array}$ & $\begin{array}{r}75 \\
128 \\
78\end{array}$ & $\begin{array}{l}\text { Normal } \\
\text { Normal } \\
\text { Normal }\end{array}$ & \\
\hline
\end{tabular}

